This item was submitted to Loughborough's Research Repository by the author.

Items in Figshare are protected by copyright, with all rights reserved, unless otherwise indicated.

\title{
Stuips, spuits and prophet ropes: the treatment of abantu childhood illnesses
} in urban South Africa

PLEASE CITE THE PUBLISHED VERSION

PUBLISHER

(c) Elsevier Ltd

VERSION

AM (Accepted Manuscript)

LICENCE

CC BY-NC-ND 4.0

\section{REPOSITORY RECORD}

Preez, Natalie Friend-du, Noel Cameron, and Paula L. Griffiths. 2019. "Stuips, Spuits and Prophet Ropes: The Treatment of Abantu Childhood Illnesses in Urban South Africa”. figshare. https://hdl.handle.net/2134/6433. 
This item was submitted to Loughborough's Institutional Repository (https://dspace.lboro.ac.uk/) by the author and is made available under the following Creative Commons Licence conditions.

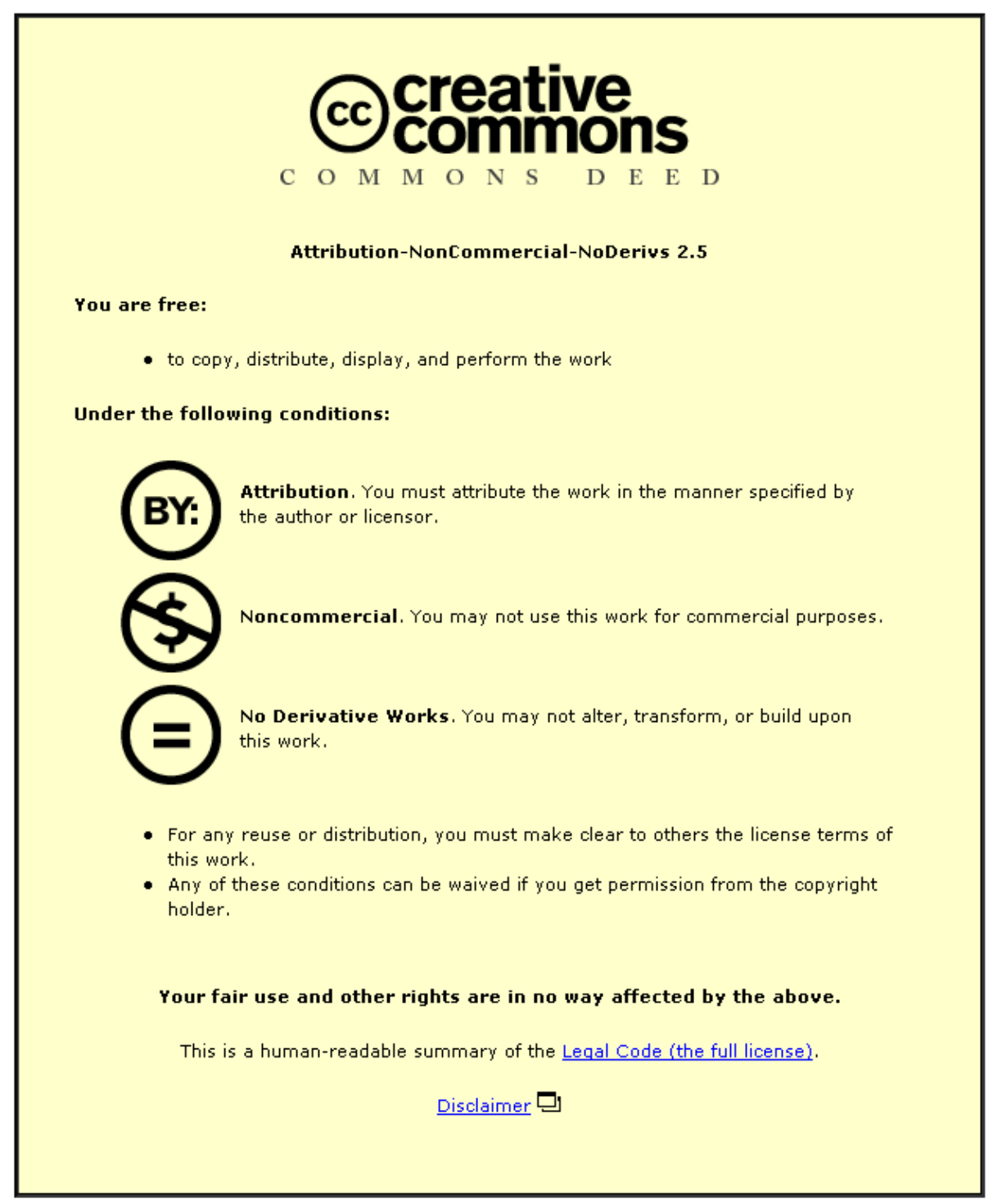

For the full text of this licence, please go to: http://creativecommons.org/licenses/by-nc-nd/2.5/ 
Details for Manuscript Number SSM-D-07-02238R1

"Stuips, spuits and prophet ropes: The treatment of abantu childhood illnesses in urban South Africa."

Corresponding Author: $\quad$ Dr Natalie Friend-du Preez

Centre for the Study of Sexual Health and HIV, Homerton University Hospital NHS

Foundation Trust London, Homerton Row, London, England, E9 6SR

Centre for Population Studies, London School of Hygiene and Tropical Medicine, 49-51

Bedford Square, London, England, WC1B 3DP

Corresponding Author E-Mail: $\quad$ frienddupreez@gmail.com; Natalie.Friend-

duPreez@lshtm.ac.uk

Acknowledgements:

The authors would like to thank the caregivers, nurses and traditional healers who gave up their time to take part in this study; the fieldworker, Shirley Vilakazi; staff at the Birth to Twenty Offices in Johannesburg and Soweto; Dr M. Mazizi, Chief Director Johannesburg \& West Rand Region (2004); the CEOs, Hospital General Mangers, Heads of Departments of the various health facilities involved; the Parkes Foundation; Professor Thea de Wet, Dr Vivienne Williams and all the participants with whom informal interviews were held.

Other Authors: $\quad$ Noël Cameron, Loughborough University, N.Cameron@lboro.ac.uk Paula Griffiths, Loughborough University, P.Griffiths@lboro.ac.uk

Keywords: $\quad$ South Africa; traditional medicine; medical pluralism; childhood illnesses; health-seeking behavior 
Abstract

With a paucity of data on health-seeking behaviour for childhood illnesses in urban South Africa, a mixed method approach was used to investigate the treatment of abantu childhood illnesses in Johannesburg and Soweto between March and June 2004. In-depth interviews were held with caregivers $(n=5)$, providers of traditional $(n=6)$ and Western $(n=6)$ health care, as well as 5 focus groups with caregivers. A utilisation-based survey was conducted with 206 black African caregivers of children under 6 years of age from 1 public clinic in Soweto ( $\mathrm{n}=50$ ), 2 private clinics in Johannesburg (50 caregivers in total), 2 public hospitals from Johannesburg and Soweto (53 caregivers in total) and 2 traditional healers from Johannesburg and Orange Farm (53 caregivers in total), an informal settlement on the outskirts of Johannesburg. The symptoms of several childhood abantu health problems, their treatment with traditional, church and home remedies, and influences on such patterns of resort are described. Despite free primary health care for children under 6 years, the pluralistic nature of health-seeking in this urban environment highlights the need for community and household integrated management of childhood illnesses and a deeper understanding of how symptoms may be interpreted and treated in the context of the local belief system.

\section{Introduction}

South African child health statistics show that further goals are yet to be reached in improving child health, particularly that of the black South African population (Solarsh \& 
Goga, 2004; UNDP, 2005; WHO, 2005). Whilst some of the disparities in health reflect the underlying economic inequalities within the population, morbidity related to the incorrect use of medicines and poor management of childhood illnesses represents a sizeable proportion of injury, disease, and mortality burden which could potentially be eliminated (Murray \& Chen, 1993; Bradshaw, Groenewald, Laubscher, Nannan, Nojilana, Norman, et al., 2003). According to Bradshaw and colleagues (2003), the major portion of childhood deaths in South Africa are from preventable causes. The WHO’s Integrated Management of Childhood Illness (IMCI) programme recognises the key role of families in a child's health care by trying to improve home case management of childhood illnesses (Claeson \& Waldman, 2000). This includes understanding how symptoms and illnesses are classified locally, as well as educating families about when children need to receive immediate medical attention.

South Africa's health care system consists of a large under-resourced public sector mostly offering free basic primary health care to about $80 \%$ of the population, a smaller well-resourced private sector for higher earners, usually members of medical aid schemes (McIntyre, Bloom, Doherty, \& Brijlal, 1995), and a very large traditional health sector. Traditional health and healing concepts run alongside the biomedical model and demand for traditional medicine is high even in urban areas (Williams, Balkwill, \& Witkowski., 1997; Good, 1987). In the early 1990s it was estimated that over 200,000 traditional healers (inyangas) and diviners (sangomas) practised in South Africa versus 25 to 30,000 'modern' doctors (Kale, 1995). Mid-1990s estimates surmise that there were 18,000 traditional medical practitioners / healers (TMPs) in Soweto alone (Williams, 1996). Towards the end 
of the 1990s, the total number of traditional healers in South Africa was estimated to be 350,000 (Bodeker, 2000).

Illnesses that are culturally bound within the black South African population are usually referred to as ukufa kwabantu [diseases of the African peoples] (Ngubane, 1977). Respondents in the current study referred to these as abantu illnesses. Although competing theories of causation and treatment may exist, general patterns can usually be found amongst healers (Green, 1999), as well as in the popular sector (Kleinman, 1980). These include witchcraft, spirits and ancestors, Supreme Being and pollution (Hammond-Tooke, 1989). The type of treatment given is usually indicative of these beliefs.

Home remedies, over-the-counter (OTC) medicines, traditional medicines and church medicines are all used to treat childhood abantu illnesses. Several Western medicines such as the antacid Muthi Wenyoni and the Dutch medicines (stuips, ditaipi, or druppels as they are more commonly known), have been indigenised into traditional health care practices (de Wet, 1998a; du Toit, 1998). Dutch medicines are phytomedicines (some containing over 50\% alcohol) introduced into South Africa by early Dutch settlers in the $19^{\text {th }}$ Century and have been in use ever since to treat a variety of ailments (de Wet, 1998a). Traditional medicines aimed at infant use in South Africa include prophylactics to protect and strengthen the child, purgatives and scarifications (Hammond-Tooke, 1981; de Wet, 1998a; 1998b). These and other remedies are available from inyangas (herbalists), and also from muthi shops, which act as wholesalers of traditional medicines (Cocks \& Dold, 2000). In order to know the cause of the problem however, a visit is usually first made to a sangoma (diviner). In the present study, children were usually taken to a gogo (older woman who is either a TMP / faith healer specialising in children's health). Of more recent 
origin are the prophets or faith healers who divine and heal within the framework of the African Independent Churches (AICs), which can be split into the Ethiopian, Zionist and Apostolic, with the latter 2 emphasizing "healing in a cosmological context” (Oosthuizen, 1989:p.73). Faith healers have not had as long a history as the traditional healers in South Africa, but there has been phenomenal growth of the AICs. Faith healers also provide prophylactics and remedies, however unlike traditional healers, most of their materia medica is inorganic (Dube, 1989; Anderson, 1992). There are instances however where Zionist faith healers as well as patients make use of herbal remedies (Cocks \& Dold, 2000; du Toit, 1980). In some cases the sangoma and faith healer have developed interchangeable roles, particularly for those in the Zionist Christian Churches (ZCCs) who believe in the power of the ancestors (Anderson, 1992).

\section{Aim}

The aim of this paper is to describe the different spheres of influence for using nonallopathic medicine for black African children under 6 years of age and to describe different medicines and treatments given for a selection of abantu childhood health problems in an urban setting in South Africa.

\section{Methods}

\section{Qualitative}


Between March and June 2004, the researcher (NFD) conducted the study under the auspices of Birth to Twenty (Bt20), the largest and longest running longitudinal birth cohort study of child health and development in Africa (http://web.wits.ac.za/Academic/Health/Research/BirthTo20). The Bt20 study provided an initial sampling frame to recruit focus group participants. The researcher, along with an interpreter, led 5 FGDs with black African mothers recruited from Bt20 for 3 groups and the paediatric dispensary queue at Baragwanath Hospital in Soweto for 2 groups. The main recruitment criterion was that the mother had a child under 6 years, for whom primary health care is free. The FGD question guide explored experiences of childhood illnesses, causes and their treatment; allopathic and traditional health care; use of traditional medicine and future health services. The researcher also conducted in-depth interviews (IDIs) with 6 representatives of traditional medicine, 5 nurses of Western medicine, 1 Western pharmacist, 1 traditional pharmacist from a muthi shop, as well as 5 caregivers of young children (based on what they had discussed during the survey). The IDI question guide for health care providers covered similar topics to the survey questionnaire and FGDs by asking questions relating to access, costs, quality, main childhood illnesses which are seen and how these are usually treated. The researchers used initial theoretical thematic analysis (manually and then using QSR NVivo) to identify themes and subthemes in the IDIs and FGDs (Stewart \& Shamdasani, 1990; Ulin, McNeill, \& Tolley, 2002) based on the overarching research questions being investigated in the main survey. Further inductive thematic analysis followed. Themes and sub-themes were grouped according to motivational schemas or 'spheres of influence' ( $v$. Figure 1$)$ - inner spheres affecting outer ones, either directly or indirectly. 


\section{Quantitative}

The researcher and a fieldworker undertook an utilisation-based survey at 4 different types of health care providers using a convenience sample of 206 black African caregivers attending with children under the age of 6 years (66\% male and 34\% female children). Recruitment took place from queues at 1 public health clinic (PHC) in Soweto ( $n=50), 2$ private clinics $(\mathrm{n}=50)$ in Johannesburg and 2 public hospitals $(\mathrm{n}=53)$ in Johannesburg and Soweto. As no queue or in-patients existed at traditional healers, 2 traditional medical practitioners / healers (TMPs) from Johannesburg and Orange Farm, an informal settlement on the outskirts of Johannesburg acted as gatekeepers to caregivers who had recently taken their child under 6 to a TMP $(n=53)$. All participants received refreshments, and a food voucher was given for taking part in the study. An interviewer-administered semistructured questionnaire collected quantitative data on the characteristics, beliefs, knowledge and actions of caregivers taking their child under 6 years to different health care providers. A number of variables measuring socio-economic status (SES) were recorded and an index measure of SES was derived using Principal Components analysis. Quartiles of relative poverty were created based on scoring only for the first principal component, with all eigenvectors positive (Cronbach’s alpha, 0.8572). Descriptive statistics were carried out using Stata 8.0 (Stata Co-operation, College Station, Texas, USA). The Department of Human Sciences, Loughborough University and the Parkes Foundation funded this study. Loughborough University and the University of the Witwatersrand's ethics committees provided ethical approval. 


\section{Results}

\section{Attitude towards non-allopathic medicines}

Traditional medicine: Overall, nearly three-quarters of caregivers had given $(n=143)$ or would give ( $\mathrm{n}=7$ ) traditional medicine (from any source) to their child if the need arose. The main types of treatments that caregivers remembered having given are found in Table 1. The most common reason for taking a child to a TMP was for protection as well as abantu illnesses which Western medicine is unable to treat ( $v$. Table 2). Of those who did not take their child to a TMP, the main reason was that they did not believe in it, closely followed by religious reasons.

\section{[Table 1]}

Faith healing: Nearly a third of caregivers had taken their child to a faith healer, as defined by the word 'abathandazeli' ( $v$. Table 2). The main faith healer users were the TMP (35.8\%) and public hospital (32\%) caregivers. The AIC and the ZCC caregivers also had stronger beliefs in the power of faith healing ( $40.4 \%$ and $37.8 \%$ respectively). Of those who had taken their child to a faith healer, $62.1 \%$ had had good results and believed that faith healing worked. Only 17.2\% had not felt that faith healing worked. Caregivers could be split into those who used traditional medicine (100 caregivers); those who used traditional medicine and faith healing (50 caregivers); those who used neither (50 caregivers); and those who used faith healing but not traditional medicine (8 caregivers).

[Table 2] 
Dutch Medicines: Just over three-quarters of caregivers had given Dutch medicines to their child ( $v$. Table 2). These were mostly used for protection from evil spirits, witchcraft and pollution. TMP, PHC and public hospital attendees were very similar in terms of their usage (83\%, 86\% and 81\% respectively), whilst the private clinic attendees had a lower proportion who had used Dutch medicines for their child under 6 (60\%). The most popular Dutch medicine overall in this sample was Haarlemensis (66\%) (v. Table 3). Forty-nine different mixing combinations were recorded in this study, of which Stuipdruppels and Haarlemensis were the most commonly mixed. The TMP caregivers used a much smaller selection of Dutch medicines than other groups.

[Table 3]

\section{Spheres of influence on use of non-allopathic medicines}

Spheres of influence ( $v$. Figure 1 ) will be discussed in terms of non-allopathic forms of health care.

[Figure 1]

The causation of illness and subsequent course of action caregivers take (traditional vs. allopathic) when their child is not well is very much governed by their own beliefs: "If you believe this one can help your kids, it can help your kids.” (FG4). Belief in the treatment, including socio-cultural reasons accounted for almost $40 \%$ of the reasons for choosing a TMP.

Religion: These beliefs are very much linked to their belief system: "You know in our church we are just different. In church you will find some people wearing sangoma things. It is because we are different, we have different beliefs, but me, I believe in God and the clinic.” (CG3 - PHC). Christianity does not always preclude the use of traditional medicine however. The highest proportion of traditional medicine users was found in the ZCC group (88.9\%) and 
the lowest in the Protestant (41.9\%) and Catholic (31.8\%) groups. In terms of faith healing, "the sick person must also have a faith in those prayers, and from those prayers and water, that person will feel alive.” (TMP1 - Zionist)

Family beliefs \& decision-making: Directly influencing a caregiver’s personal beliefs are the beliefs of her own family and the family she has married into: "I did this because I also grew up using them and that is part of my family norms, that each and every child must be treated with these traditional things.” (FG4). Because "grannies - they know everything” (FG3), they exert a big influence over whether a child goes to a TMP or not, with $93.3 \%$ of children whose granny is the decision-maker having taken the child to a TMP $\left(\chi^{2} \mathrm{P}\right.$ value $\left.=0.016\right)(v$. Table 4). Problems were found to arise when families have different beliefs, with:“[husband’s family] blaming me! They’re blaming me because of my beliefs.” (FG4).

Social networks: The importance of the lay referral system cannot be underestimated: "For us to know that an inyanga is good, we hear it from others, like for example if you come and say to me my child is sick what is wrong with your child? My child has epilepsy or my child has inyoni. And then I would say there is a good traditional healer who helped my child and cured him from inyoni and ibala.” (CG5 - public hospital). One reason TMP caregivers cited for continuing to use a TMP, even if they won the lottery, would be because they would not want friends to think they are different.

Child's age: A child's age may influence where a caregiver takes her child or what medicines are used because of the fragility of younger babies, perceived vulnerability and the need for protection from natural and supernatural contagions: “...not now, but when he was 
still young. Now I am not using any stuips. I was using the stuips whilst the child was still young.” (CG1 - public hospital).

Characteristics of the illness: Symptoms may affect where a child is taken if these are perceived to be markers of a traditional illness or problem requiring non-Western prophylactics or medicines.

Education: Education was a strong predictor of the use of traditional medicine, with 93.8\% of caregivers with primary school education or less having given their child traditional medicine compared with $57.1 \%$ of those with post-secondary education $\left(\chi^{2} p\right.$ value $\left.=0.006\right)$.

Socio-economic status: Overall, the TMP group had the largest proportions of very low and low SES. Proportionally, those on lower household incomes (below R1500 (US\$83: 2004 rate) per month) are more likely to use traditional medicine (nearly 80\%) than those with higher household incomes (over R6000 (US\$333) per month) $(47.1 \%)\left(\chi^{2}\right.$ p value $\left.=0.009\right)$.

Cost: Nearly a quarter of the total sample thought that traditional medicine was cheap, 21.4\% thought it was affordable, 33\% thought it was expensive and 20.9\% did not know. Although the caregivers interviewed at the TMPs considered traditional medicine to be cheaper than other groups, the lowest SES group still found it to be expensive. Traditional healers do charge for their services, but payment structures may be flexible, depending on the healer: "But I sometimes feel sorry for those who don't have money and tell them to pay whenever they have the money.” (TMP4).

Distance: Nearly three-quarters of private clinic and public hospital caregivers were at the provider they cited as furthest from where they lived. PHC (76\%) and in particular TMP (94.3\%) caregivers were at a provider that was nearest to where they lived. TMP patients may, 
however, forgo the extra costs of travelling if the service, including outcome, is of high quality: “They don’t even mind how far it is, what they want, is to be helped.” (TMP6).

Opening hours: Because their services are their source of income, TMPs are more likely to make them more available: "Sometimes you might find that they are sick and it's night, and when they go to the clinic, they find it closed, and they decide to come to us, because we don’t sleep.” (TMP1). However TMP6 reported that healers were not meant to work at night as "you have to sleep so that you can communicate with your ancestors.”

Staff and drug shortages at clinics: Medicine shortages, particularly at clinics, may lead some caregivers to use home remedies or traditional medicine: “At least giving her something is better than nothing... At times, you will find that they go to the clinic and when they get there they are just told to go back home, because there are no medicines. And then because of those things, they will just come to me for help.” (TMP1).

Trust and efficacy: If money was not a problem, over half of TMP caregivers stated that the TMP would continue to be the best place for any treatment because they know and trust the TMP and don't really know about private clinics. Efficacy of treatment in the past was another main reason for choosing a TMP. If a caregiver has had success with a certain treatment or provider in the past, or if she knows of someone who has, she is more likely to use this again: "Iya, it helps. I took my child to the clinic I think 3 times with the same problem until I applied this thing and he was healed. Sunlight, pure Sunlight [soap] and Colgate.” (FG5). The ineffectiveness of Western medicines to help the problem is a key factor in treatment-switching: "They will come and tell me that they started at the doctor, saying that they have about two weeks seeing the Western doctor, then I will stop them from using the medicines they have, and start using mine.” (TMP3). 
[Table 4]

\section{Treating childhood abantu illnesses in Johannesburg and Soweto}

Figure 2 shows the health problems, symptoms and reasons for which traditional medicines were given in the present study as described by caregivers, TMPs and nurses. Similar illness aetiology groupings to that of Hammonde-Tooke (1989) were identified, however there was not always a clear distinction between categories.

[Figure 2 here]

\section{Problems with overlapping causes and treatments}

The most well-known abantu illnesses found in this sample of caregivers were inyoni ([Zulu: bird], also known as phôgwana / kogkwana / hlôgwana (Sotho), ikhakhayi or ipleyiti [plate] (Xhosa)) and ibala, the causes of which were not always known and which sometimes overlapped. From a Western perspective, inyoni “it’s pure gastro.” (Nurse 1 public hospital) and ibala is capillary naevus, which usually appears as temporary patches of red or purple skin discolouration in approximately $40 \%$ of all newborns, usually on the nape of the neck, on the forehead between the eyebrows or on the eyelids (Dermet NZ, 2004). The main indigenous representation of ibala is "a red mark at the back of the neck. That mark is dangerous because it moves.” (TMP5). The red mark is also "sometimes on the fontanelle... It is red in colour and usually suppresses the child and the child becomes weak, restless...” (CG5 - public hospital). It was considered to be "dangerous if a child has it and once the child bleeds through the nose he ends up dying.” (TMP2). The main indigenous representations of inyoni include green faeces, "like the child has been eating leaves” (CG4 - private clinic), ishashaza [oral thrush / rash] and the fontanelle sinking in. Other symptoms include "green veins in the tummy and it becomes bloated and doesn't 
like eating when he's like that." (TMP2). According to TMP1, "it is not the same thing as diarrhea.” Both pollution (particularly through breastfeeding) and witchcraft were causes mentioned by TMPs in relation to both illnesses. Common to both inyoni and ibala is the idea of pollution during pregnancy, as well as more tangible 'things' on the mothers vagina or "ishashaza on your private parts” (TMP6), which are transferred during birth or breastfeeding. Although the cause of inyoni was generally unknown by caregivers, it was acknowledged that 'dirt' in the child's system needed to be cleaned out.

Amongst caregivers interviewed at the 4 different health care providers, the antacid Muthi Wenyoni was the main OTC treatment used for inyoni (52.1\%), besides Gripe Water and various Dutch medicines. Muthi Wenyoni (15\%) and Dutch medicines were also used for ibala. The main named traditional treatments that caregivers knew of for ibala were ukunquma [scarifications], usually on the red mark on the back of the neck, but also on other parts of the body. Traditionally, scarifications behind the ears, on the forehead, around the belly button and on joints are usually treated with a black powder / paste known as mohlabelo [(Sotho) and umhlabelo (Zulu)] to strengthen the child. This was also used for inyoni. A similar treatment involves cutting either the nails and hair or 'things' from the vagina, burning them, mixing them with muthi then rubbing this onto joints and the fontanelle.

Although caregivers were generally unaware of the contents of the imbizas and spuits, referring to them as imbiza yabantwana [children's imbiza], they reported using an imbiza called 'Double Nonsense’ which contained inGcino / letshwetlane [Albuca setosa / Scilla nervosa] to treat both ibala and inyoni. Other imbizas contained ilitshe lomgodi [ground stone]; umtholo [Acacia caffra (root)]; intsizi [black powder (burnt herbs and 
animal fats)] mixed with milk to drink; molemo [Setswana: remedy, medicine]; umuthi ubomvu [red medicine]; isiwasho and an onion-like bulb (may be inGcino); isiphepheto / serokolo [Siphonochilus aethiopicus (root)]; herbs boiled from the bush; ginger and other green leaves from the garden; iQhuma (both a traditional medicine [Intuma - Solanum species] and OTC antacid); and ground ostrich egg. As well as inGcino, other spuit [enema] ingredients included isiwasho [ash-based medicine], Sunlight soap and an imbiza containing milk.

Other traditional treatments included ear, nose and mouth drops (unknown ingredients); pricking the child with inungu [porcupine quills] as well as performing the ukuhlala [Zulu: to bury] ritual whereby "the healer asks you to bring an item that the child first wore after birth and a spuit... He then cuts the child on the head, the arms, right around the belly button and the child's feet with a razor blade. He twists wool to make a rope to wear across the child's chest. From there we leave his house to go to the mountain. The healer wipes the blood from the cuts, then he will give the child the spuit with a bucket of umuthi and the child's faeces will come out. After that he will hold the child and say something that we don't understand.” (CG5 - public hospital). This ritual was similarly described by TMP5, who referred to the enema as imbiza wenyoni and CG1 (public hospital) who said that you "must leave maybe something like a vest, an old thing" in the hole. Traditional healers such as TMP3 do refer patients to Western health facilities, even for abantu illnesses if the child is worse "to be put on drips for more water, since their body needs more water.” However once the symptoms are gone, the healers reported that the child still needs traditional treatment to get rid of the cause of the problem. 
Church medicines included green ropes with amulets attached; prophet ropes worn around the waist; oil from the church; isiwasho and water to drink; imithi / isiwasho for in the bath; a mixture of water, coffee, fish oil given every day until the child is 4 months old; black tea with water and prayer. Home treatments included burning incense such as Doepa, garlic and boiled water to drink and crushed tomato leaves with the 'original' white Colgate toothpaste (i.e. no microcrystals / whitening agents) either inserted into the child's orifices or rubbed on the red mark. For inyoni, only 7 caregivers cited either oral rehydration solutions, boiled water to drink, glucose or drips / drip in the head to stop the 'beating fontanelle'.

\section{'Pollution'-related health problems and treatment}

The anthropological term 'pollution' denotes an illness contracted from coming into contact with a person or a place that is in a 'polluted' or impure state and is usually associated with birth and death (Hammond-Tooke, 1989; Ngubane, 1977). Chewing the root isiphepheto and applying it to the child's fontanelle by the person who is ritually impure was identified as one form of protection against these types of pollution during FGDs.

Pollution beliefs were also found regarding the effect of breast milk on the child's health, whereby "they have this notion that it's from the dirty milk, that's why the child is getting this bloated stomach and the green veins” (Nurse1 - public hospital), also referred to as masebela. Following birth there are therefore beliefs that the child regularly needs to be given a purgative, "cleaning all dirty things in their stomach. Maybe she can do that twice in a week.” (TMP3). Enema ingredients for masebela include utshwala-bezinyoni 
[Red dagga (marijuana), Leonatis leonurus], umasango [insangu (Cannabis sativa)] (TMP5) or milk (TMP3) in a spuit.

Pollution is also one way that a child may develop inkaba [umbilicus that won't heal]. According to TMP2, TMP5 and TMP6, inkaba may also be caused by the clotted blood [ivangazi] on the inside of the umbilicus burning the child and causing them to cry a lot. Dutch medicines are given to the child and incisions are made around the umbilicus and black ashes or a similar ointment is rubbed into the cuts. The incisions help to "take out the blood that is blocked by the clip that the hospital puts on.” (TMP2). Other treatments included burning imphepho [Helichrysum species], Doepa, isiphepheto or umzane / inyamazane [powder made up of various dried animal parts]; giving the child a spuit, Muthi Wenyoni or performing rituals such as ukhlala.

Isilonda, is a sore painful spot or wound, and in this context it refers to the area around the child's anus, which from a Western perspective is associated with "constant diarrhea and it causes prolapse of the rectum” (Nurse1 - public hospital). According to indigenous representations of isilonda / umtwana udliwe [Zulu: the child is being eaten] there is both a natural (isilonda umkhuhlane) and a supernatural cause (isilonda somoya). According to TMP2, with isilonda somkhuhlane the child "closes his eyes and he sleeps a lot... his stools are loose and when you open his bottom you'll find that it's red.” With isilonda somoya "they [stools] are yellow. They are like sour milk. And the bottom turns red and is pushed out.” Treatments include giving an imbiza yabantwana, as well as burning traditional medicines. Named traditional treatments for isilonda included molemo mixed with ilitshe lomgodi and umphuphuto [Graderia scabra]. These treatments are applied using a spuit, although TMP4 did not like to use a spuit if the problem was serious 
"because he [the child] has lost strength.” (TMP4). If uhlanga [reed / dry stalk] is not available, "you can use a ball pen - the fine point one. The sharp side you can push it inside the child's bottom and push it slowly using Vaseline.” (TMP2). Focus group participants revealed that "if ever my child has sores in his bottom, I take a bit of the Colgate and then I put a bit of the Sunlight [soap], and I just put it on a pen, then I round it over like this, then I put at the back [anus] and it helps.” (FG5).

\section{Strong medicine-related health problems and treatment}

Other contagions include the fumes of strong or bad traditional muthi. Those which may be inhaled are referred to as imimoya emibi [bad spirits] if they are harmful (Ngubane, 1977; de Wet, 1998a). If a child has not been properly strengthened and they inhale the strong medicines, a process known as kuhabula (rhabula or khabula), they may be "overpowered" (FG2) and "when the child is weak it is easy that they might die from those muthis." (TMP3). Tell-tale signs include the child not being able to sleep and "the child will cry for the whole night because of those muthi. Children can easily sense things that are not good...” (TMP3); “And this thing [fontanelle] falls in... you see if the child was suppressed or was exposed to strong medicines his food comes through his nose. The other thing you will see when the child starts having running stomach and it is like he was exposed to stuips.” (FG2). Another sign is that the child will have igwebu [foam] coming out their mouth when they cry (TMP1).

If a child who has been given muthi comes into contact with a child who has not, rituals can be performed. This involves stretching the other child's limbs (joints), or "if you don't stretch the child, you take the child, you just turn him around and take the head of the 
other child - that one must touch each other...” (FG4). In this way the child will not be suppressed.

\section{Imimoya emibi and witchcraft-related health problems and treatment}

There are many forms of sorcery including putting 'muthi traps' on paths where people walk (Hammond-Tooke, 1989; Ngubane, 1977). TMP5 revealed that "sometimes you find that, that muthi trap [imikhondo / inyamazane] was not meant for you, but it can affect a child.” (TMP5). In some cases this is intentional and "they are just things being created intentionally by jealous people.” (TMP6).

If a child cries at night this may be "a sign that there are evil spirits around the house." (CG5 - public hospital). If doctors had told a caregiver her child was fine but "it's [child] still crying, that makes me worried because he's still crying and they say there's nothing with him or maybe there’s the witch thing somewhere.” (CG2 - public hospital). According to TMP6, "when the child has got tokoloshe [water sprite used by witches], obviously the child will end up dying.” Fortunately, "you can heal the child when she has got tokoloshe... Yes, there are those medicines which you have to mix, Stuipdruppels and Haarlemensis... Mix with Doepa as well, and smear the child with it, by that you will make the child drunk.” (TMP6). Dutch medicines were widely used to protect the child from evil spirits, protection against other people using traditional medicine, and when going out. As well as drops being added to the bath and put in milk, they are also rubbed on the child “where there’s holes because it’s still soft here, everything [evil spirits / strong medicine] can go there.” (CG2 - public hospital). Given the malodorous and strong medicinal properties of the Dutch medicines, not everyone uses them for children because "he ends 
up coughing, he has chest problems and other things, because that's dangerous for him.” (CG3 - PHC). Caregivers who come "smelling of those stuips" are also warned by nurses “don’t put these things on the child because it suppresses the respiratory centre and the child goes like [makes wheezing sound].” (Nurse1 - public hospital). Nurses understood that caregivers "they do [use them], a lot of them. And they believe a lot in them", but they "always teach them, you must read the leaflets and see what are those treatments for, because some of them, most of them are treatments for adults, not for children.” (Nurse2 public hospital).

One of the main treatments used for imimoya emibi were umuthi ukushunqisa [medicines which are inhaled] such as imphepho, inyamazane, isiphepheto and Doepa. If imimoya emibi are thought to be the cause of the child's restlessness, "then you make the child inhale the smoke” (FG4) and "the evil spirit will be thrown out of their body." (TMP1). In the present study a private clinic caregiver also mixed the ashes of inyamazane and Doepa with Vaseline "so they become like a paste." (CG4 - private clinic). Vimbela, a Vaseline-based traditional medicine can also be smeared on the child's body for protection, the ncweba, a small bag containing medicines or charms for protection and strengthening may be worn around the neck or prophet ropes worn around various parts of the child's body.

\section{Ancestor-related health problems and treatment}

If customary rites and rituals to honor the ancestors are not performed the ancestors may withdraw their protection (Ngubane, 1977; Gumede, 1990) and "the child could get sick or the child could die." (CG4 - private clinic). This is because "they share the child with the 
ancestors... Now if you don't think about that then she [ancestor] will show you through the baby to let you know that she’s here.” (TMP5). The child crying a lot may also be a sign from the ancestors, “like now he’s crying we think and know because with my first born it was the same... but after I slaughtered the sheep and talked to the ancestors he stopped crying.” (CG2 - public hospital). Other rituals include making “traditional beer [umqombothi] and I made a request that I be allowed to call her Busisiwe up until such time where I can afford to make the normal naming ceremony for her... I slaughtered a goat... a part of a goat's skin you have to cut it in a certain way and its round like this and you put it on her wrist. It’s called isiphandla.” (CG4 - private clinic).

One childhood illness believed to be caused by the ancestors is umlilo wamadlozi [Zulu: burns from the ancestors] in which "the child becomes pink in colour, and look as if there is something in her stomach that makes her thin. The child will look like she is burned. At the hospital they call it cauliflower [Kwashiokor]. You will find that she doesn't eat.” (TMP1). From a nurse’s perspective, “we call it weeping dermatitis, medical term. The skin goes black and peels off, and the child is bloated, and you look at them, they look like a bulldog... They wouldn't just out of their own tell you. It's when you start and probe and say this is Kwashiorkor, a protein deficiency disease... and then she says, no, it's the ancestors’ burns.” (Nurse1 - public hospital).

\section{Discussion}

Although utilisation surveys reduce recall bias, thereby giving greater validity to the study results, the convenience sampling procedure and utilisation-based survey design prevent the generalisability of results. Furthermore, not everyone who has an illness or medical 
condition consults a doctor. Neither was it possible to interview caregivers at other types of health facilities such as pharmacies, muthi shops or general practitioners given the faster turnover of patients / customers at these providers and because of the timescale needed to acquire a large enough sample. Despite these limitations, the facility-based approach allowed a deeper locational analysis of characteristics, beliefs, knowledge and actions of caregivers attending different health care providers which population-based surveys are unable to provide. Utilisation-based surveys are also better at overcoming under-reporting of the use of traditional medicine by finding out about the behaviour of traditional healers' patients (Good, 1987). Combined methods were used in order to better illuminate the complexity of health service utilisation, particularly at a micro level.

Although primary health care is supposed to be the most equitable level of care, many health districts are under-served and great variation is seen in per capita spending (Ntuli \& Day, 2004). Eighty-six percent of the Orange Farm caregivers cited the primary health care clinic as their furthest provider. For this reason they were likely to use the services of a gogo not solely for abantu illnesses. Access to and quality of primary health care is therefore not always uniform and is more likely to affect the most disadvantaged in society. Regardless of provider characteristics, caregiver beliefs are at the heart of the decision-making process, and in the urban South African context these relate much to the treatment being used and faith that they will work. The main reasons for using traditional medicine were for supernatural or abantu illnesses, because Western medicine could not help, and because of the caregiver's background and family influence. The findings from this study build on those found in previous rural South African studies (Bland, Rollins, Van den Broeck, Coovadia, et al., 2004; Kauchali, Rollins \& Van den Broeck, 2004; Cocks \& 
Dold, 2000; Hammond-Tooke, 1989; Ngubane, 1977; Tyiso \& Bhat, 1998) by adding to the knowledge base of childhood abantu health problems and their treatments in both high and low SES groups, describing these within an urban setting where there is a wider variety of health care options available and taking into account the views of both caregivers and health care providers.

The various remedies and materia medica described in this paper illustrate the pluralistic nature of medical treatment in this context. Within popular medicines, socially constructed medicinal uses have been given to household products. A simple search on Google will find toothpaste (which often contains baking soda) cited as a home remedy for rashes and acne. It is not surprising therefore that the 'original' white Colgate toothpaste with no abrasive agents or irritants such as hydrogen peroxide has made its way into the pharmacopoeia for isilonda. Household detergents have also been incorporated into enemas as a result of their cleansing properties. If enemas are to be given at home, they should generally not be used in children under 2 years of age and advice should first be sought from a health care provider (Schmitt, 1991). Soapsuds, hydrogen peroxide, plain water or herbal enemas should not be used as these may have negative health effects (Moore \& Moore, 1998). Further biomedical evidence shows that although the ingredients may not always be toxic, an incorrect dosage may make them so (Popat, Shear, Malkiewicz, Stewart, Steenkamp, Thomson \& Neuman, 2001). For instance, informal interviews with TMPs and caregivers in the present study revealed that one method of measuring traditional medicine was referred to as ilungu or ilunga, meaning the distance between 2 finger joints or the tip of a finger, regardless of the size of the container. 
Western medicines that have made their way into the traditional pharmocopeia include the antacid Muthi Wenyoni and the Dutch medicines. Although not all Dutch medicines were administered orally, some Dutch medicines used by caregivers are not intended for use in young children. In many instances they may be used as recommended by friends and relatives, particularly if no instructions are found on the box. In the present study, $57 \%$ of caregivers who would use Muthi Wenyoni to treat inyoni had secondary or higher education, $46 \%$ had medium or higher SES, suggesting that this practice is not confined to lower SES households. A decade after de Wet's findings, the pharmaceutical industry appears to continue to exploit indigenous beliefs about health and illness. That biomedical and traditional views on treating or preventing illness may conflict (Liddell, Barrett \& Bydawell, 2005) is particularly evident in the use of enemas and Muthi Wenyoni, particularly for inyoni. Traditional healers did however acknowledge the importance of the ‘drip’ from the hospital for illnesses such as inyoni and ibala, however not all caregivers understood the function of the drip. Sixteen caregivers (4 public hospital, 4 PHC clinic, 1 private clinic and 7 TMP) thought that it would stop vomiting or diarrhea whilst 2 caregivers thought that it cleaned the system.

\section{Conclusion}

The third component of the WHO and UNICEF IMCI strategy (household and community IMCI) is important for empowering communities to explore and address issues that facilitate or impede key family practices for effective child health care, yet this component has remained underdeveloped in South Africa (Andrews \& Pillay, 2005). 
Relevant to health-seeking behavior and child health care initiatives in the wider subSaharan African context, the findings from this research suggest that health education campaigns should pay attention to the symptoms that mothers themselves recognise as significant (Yoder \& Hornik, 1996) and incorporate these into cues for how best to treat the illness, including abantu illnesses. Although many of these treatments may be effective, caregivers should be made aware of the dangers of using enemas, particularly those containing detergents. Advice on the potential dangers of overusing medicines containing alcohol, or the misuse of medicines intended for adults, should be communicated clearly and effectively by health care providers, giving caregivers the opportunity to ask questions (especially if they have found such treatments to be effective) and not feel that they are being reprimanded. Findings here suggest that many caregivers are aware of the negative views held by many Western health care providers about traditional medicines and remedies, however the strength of their beliefs in the efficacy of such treatments means that health messages may go unheeded. For caregivers interviewed at the TMPs, a particularly salient issue was that of the integration of traditional and Western medicine, if not in the organisational sense, at least in terms of clinic and hospital staff showing more respect towards traditional medicine and cultural beliefs. Since traditional healers continue to remain important providers of health care in urban South Africa it is therefore important that all traditional healers are offered training to recognise important signs and symptoms of childhood illnesses which require referral to a clinic or hospital. Liaising with traditional healers as part of community-based services is already on the agenda for STDs (Department of Health, 2001) and should be expanded to include traditional healers as information, education and communication (IEC) agents in the community component of 
IMCI. Western medical staff should also be given training on abantu health problems and their treatments. By showing knowledge of these practices, health care providers may be perceived as more approachable. It may also help them in understanding their patients' health-seeking behaviour in the context of the local belief system and negotiating treatments. 


\section{References}

Anderson, A., (1992). Prophetic Healing and the Growth of the Zion Christian Church in South Africa. Paper presented at the NERMIC conference, July 1993. URL: http://artsweb.bham.ac.uk/aanderson/ Accessed 07/12/2004.

Andrews, G., \& Pillay, Y. (2005). Strategic priorities for the national health system (20042009). contributions towards building a model development state in South Africa. In P. Ijumba, \& P. Barron, (Eds.), South African health review (SAHR) (2005) (pp. 2-15). Durban: Health Systems Trust.

Bodeker, G. (2000). Planning for cost-effective traditional health services. In WHO. Traditional medicine, Better Science, Policy and Services for Health Development (pp. 31-70), Awaji Island, Hyogo Prefecture, Japan, 11-13 September 2000.

Bland, R., Rollins, N., Van den Broeck, J., Coovadia, H., \& Child Health Group. (2004). The use of non-prescribed medication in the first 3 months of life in rural South Africa. Tropical Medicine \& International Health, 9(1), 118.

Bradshaw, D., Groenewald, P., Laubscher, R., Nannan, N., Nojilana, B., Norman, R., Pieterse, D., Schneider, M., Bourne, D.E., Timaeus, I.M., Dorrington, R., Johnson, L. (2003). Initial Burden of Disease Estimates for South Africa, 2000. Cape Town: Medical Research Council. URL: http://www.mrc.ac.za/bod/initialbodestimates.pdf Accessed 20/01/06.

Claeson, M., \& Waldman, R.J. (2000). The evolution of child health programmes in developing countries: From targeting diseases to targeting people. Bulletin of the World Health Organization, 78(10), 1234-1245. 
Cocks, M. \& Dold, A. (2000). The role of 'African Chemists' in the health care system of Eastern Cape province of South Africa. Social Science and Medicine, 51, 1505-1515. Department of Health (2001). The Primary Health Care Package for South Africa - a set of norms and standards. Pretoria: Department of Health.

de Wet, T. (1998a). Doepa after dark: Protective medicines for infants in Soweto, South Africa. Ph.D. Dissertation. University of Florida.

de Wet, T. (1998b). Muti Wenyoni: commodification of an African folk medicine. South African Journal of Ethnology, 21(4), 165-172.

du Toit, B. (1980). Religion, ritual and healing amongst among urban black South Africans. Urban Anthropology, 9(1), 21-49.

du Toit, B. (1998). Modern folk medicine in South Africa. South African Journal of Ethnology, 21(4), 145-153.

DermNet NZ (2004). Capillary Vascular Malformation. URL: http://dermnetnz.org/vascular-malformation.html Accessed 10/09/04. Dube, D. (1989). A Search for Abundant Life: Health, Healing and Wholeness in the Zionist Churches. In G.C. Oosthuizen, S.D. Edwards, W.H. Wessels, \& I. Hexam (Eds.), (1989). Afro-Christian religion and healing in Southern Africa (pp. 109-136). United Kingdom: The Edwin Mellen Press Ltd.

Good, C.M. (1987). Ethnomedical systems in Africa. New York: The Guildford Press. Green. E.C. (1999). Indigenous theories of contagious disease. California: Altamira Press, A Division of Sage Publications.

Gumede, M.V. (1990). Traditional healers. A medical doctor's perspective. Johannesburg: Skotaville Publishers. 
Hammond-Tooke, W.D. (1981). Patrolling the herms: Social structure, cosmology and pollution concepts in Southern Africa. Johannesburg: Witwatersrand Press.

Hammond-Tooke, W.D. (1989). Rituals and medicines. Johannesburg: AD Donker.

Kale R. (1995). Traditional healers in South Africa: a parallel health care system. British Medical Journal, 310, 1182-1185.

Kauchali, S., Rollins, N., \& Van den Broeck, J. (2004). Local beliefs about childhood diarrhea: Importance for healthcare and research. Journal of Tropical Pediatrics, 50(2), 82-89.

Kleinman, A. (1980). Patients and healers in the context of culture. An exploration of the borderland between anthropology, medicine and psychiatry. Berkeley: University of California Press.

Liddell, C. Barrett, L. \& Bydawell, M. (2005). Indigenous representations of illness and AIDS in Sub-Saharan Africa. Social Science and Medicine, 60, 691-700.

McIntyre, D., Bloom, G., Doherty, J., \& Brijlal, P. (1995). Health expenditure and finance in South Africa. Durban: Health Systems Trust and the World Bank. URL: http://www.hst.org.za/uploads/files/hstefsa.pdf Accessed 23/03/06.

Moore, D.A. \& Moore, N.L. (1998). Paediatric enema syndrome in a rural African setting. Annals of Tropical Paediatrics, 18, 139-154.

Murray, C.J.L., \& Chen, L.C. (1993). In search of a contemporary theory for understanding mortality change. Social Science and Medicine, 36(2), 143-156.

Ngubane, H. (1977). Body and mind in Zulu medicine. London: Academic Press. 
Ntuli, A., \& Day, C. (2004). Ten years on - have we got what we ordered? In P. Ijumba, C. Day, \& A. Ntuli (Eds.), South African health review (SAHR) (2003/2004) (pp. 1-10). Durban: Health Systems Trust.

Oosthuizen, G.C. (1989). Indigenous healing within the context of the African Independent Churches. In G.C. Oosthuizen, S.D. Edwards, W.H. Wessels, \& I. Hexam (Eds.), (1989). Afro-Christian religion and healing in Southern Africa (pp. 71-90). United Kingdom: The Edwin Mellen Press Ltd.

Popat, A., Shear, N. H., Malkiewicz, I., Stewart, M., Steenkamp, V., Thomson, S., \& Neuman, M. (2001). The toxicity of Callilepis laureola, a South African traditional herbal medicine. Clinical Biochemistry, 34(3), 229-236.

Schmitt, B.D. (1991). Your child's health: The parents' guide to symptoms, emergencies, common illnesses, behavior, and school problems. New York: Bantam Books.

Singer, M., Davison, L., \& Gerdes, G., (1988). Culture, critical theory, and reproductive illness behaviour in Haiti. Medical Anthropology Quarterly, 2, 370-385.

Solarsh, G., \& Goga, A. (2004). Child health. In P. Ijuma, C. Day, \& A. Ntuli (Eds.), South African health review (SAHR) (2003/2004) (pp. 101-128). Durban: Health Systems Trust.

Stewart, D. \& Shamdasani, P. (1990). Focus groups. Theory and practice. Applied social research methods series, Volume 20. California: Sage Publications.

Tyiso, S. \& Bhat, R. B. (1998). Medicinal plants used for child welfare in the Transkei region of the Eastern Cape (South Africa). Angewandte Botanik, 72, 92-98.

Ulin, P.R., McNeill, E.T., \& Tolley, E.E. (2002). Qualitative methods: A field guide for applied research in sexual and reproductive Health. USA: Family Health International. 
UNDP (2005). Human Development Report 2005. International cooperation at a crossroads: Aid, trade and security in an unequal world. New York: United Nations Development Programme.

WHO (2005). Annex Table 2a Under-five mortality rates: estimates for 2003, annual average percent change 1990-2003. URL:

http://www.who.int/whr/2005/annex/annex2a.xls Accessed 20/01/06.

Williams, V. (1996). The Witwatersrand muti trade. Veld and Flora, 82, 12-14.

Williams, V. L., Balkwill, K., \& Witkowski, E.T.F. (1997). Muthi traders on the Witwatersrand, South Africa - an urban mosaic. South African Journal of Botany, 63(6), 378-381.

Yoder, P. S., \& Hornik, R. C. (1996). Symptoms and perceived severity of illness as predictive of treatment for diarrhea in six Asian and African sites. Social Science and Medicine, 43, 429-439. 
Table 1: The main traditional medicine types that caregivers remembered having given to their child under $6^{\text {a }}$

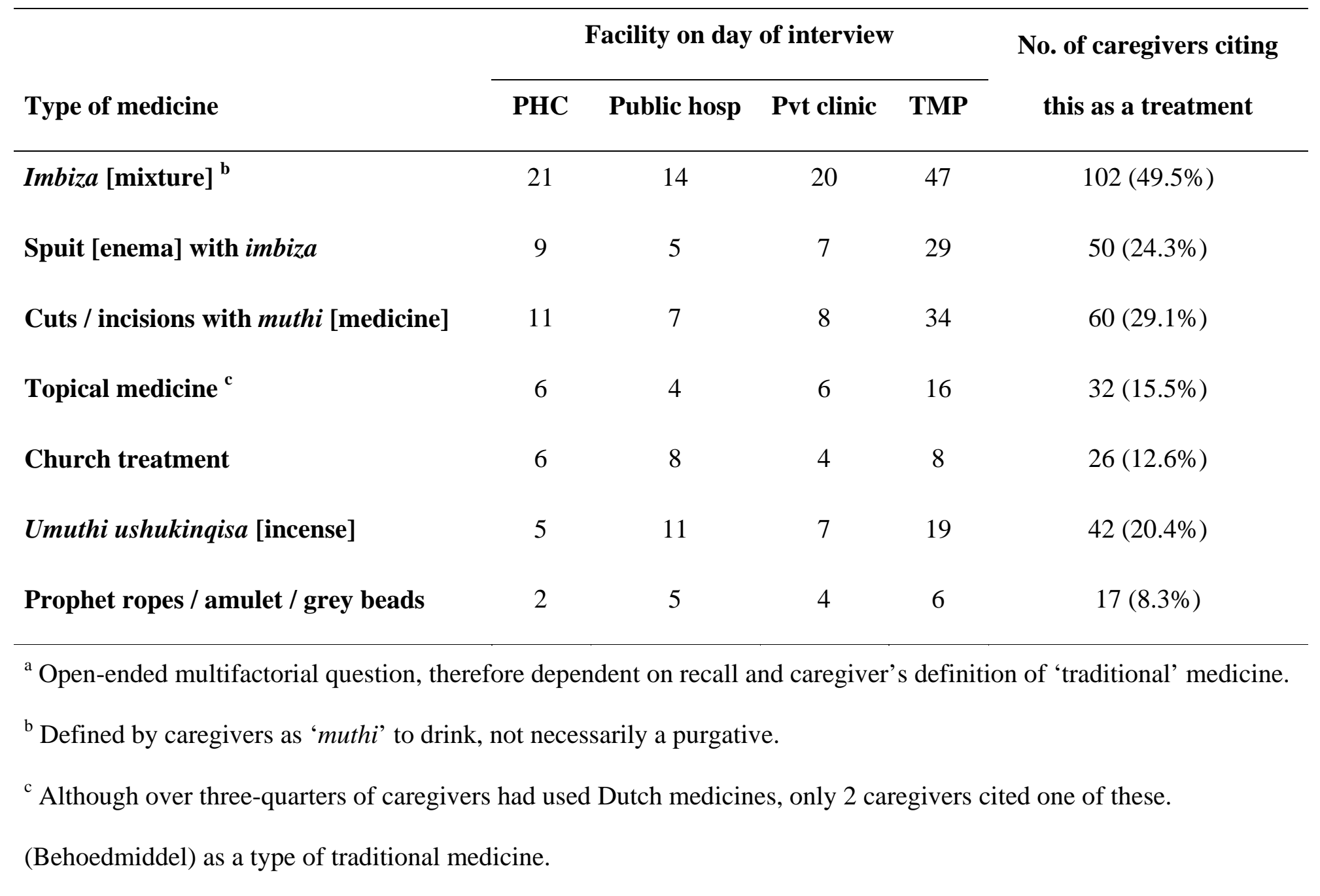


Table 2: Characteristics of caregivers and use of non-allopathic medicine by facility on day of interview

\section{Facility on day of interview}

\begin{tabular}{llll}
\hline PHC & Pub hosp & Pvt clinic & TMP
\end{tabular}

$$
(n=50) \quad(n=53) \quad(n=50) \quad(n=53) \quad(N=206)
$$

Socioeconomic status (SES) score ***

\begin{tabular}{|c|c|c|c|c|c|}
\hline Very low & $12(24 \%)$ & $14(26.4 \%)$ & $0(0 \%)$ & $21(39.6 \%)$ & $47(23 \%)$ \\
\hline Low & $16(32 \%)$ & $21(39.6 \%)$ & $3(6 \%)$ & $26(49.1 \%)$ & $66(32 \%)$ \\
\hline Medium & 17 (34\%) & $15(28.3 \%)$ & $13(26 \%)$ & $6(11.3 \%)$ & $51(25 \%)$ \\
\hline High & $5(10 \%)$ & $3(5.7 \%)$ & $34(68 \%)$ & $0(0 \%)$ & 42 (20\%) \\
\hline \multicolumn{6}{|c|}{ Religious affiliation $* * *$} \\
\hline Catholic & $5(10 \%)$ & $5(9.4 \%)$ & $11(22 \%)$ & $1(1.9 \%)$ & $22(11 \%)$ \\
\hline ZCC & $9(18 \%)$ & 10 (18.9\%) & $6(12 \%)$ & $20(37.7 \%)$ & 45 (22\%) \\
\hline$A I C$ & $15(30 \%)$ & $16(30.2 \%)$ & $11(22 \%)$ & $15(28.3 \%)$ & 57 (28\%) \\
\hline Protestant & $15(30 \%)$ & $16(30.2 \%)$ & $22(44 \%)$ & $9(16.9 \%)$ & $62(30 \%)$ \\
\hline None & $6(12 \%)$ & $6(11.3 \%)$ & $0(0 \%)$ & $8(15.1 \%)$ & $20(10 \%)$ \\
\hline
\end{tabular}

Caregiver's highest education level reached $* * *$

\begin{tabular}{llllll}
\hline None / complete primary & $5(10 \%)$ & $8(15.1 \%)$ & $1(2 \%)$ & $18(33.9 \%)$ & $32(15.5 \%)$ \\
Some secondary & $23(46 \%)$ & $23(43.4 \%)$ & $3(6 \%)$ & $25(47.2 \%)$ & $74(35.9 \%)$ \\
Complete secondary & $19(38 \%)$ & $17(32.1 \%)$ & $12(24 \%)$ & $10(18.9 \%)$ & $58(28.2 \%)$ \\
Higher & $3(6 \%)$ & $5(9.4 \%)$ & $34(68 \%)$ & $0(0 \%)$ & $42(20.4 \%)$ \\
\hline
\end{tabular}

Use of traditional medicine for child under $6 * * *$ 
Has given / would if need arose ${ }^{a}$

$34(68 \%) \quad 34(64.2 \%) \quad 29(58 \%) \quad 53(100 \%) \quad 150(72.8 \%)$

Has never / would never give

$16(32 \%)$

19 (35.9\%) 21 (42\%)

$0(0 \%)$

$56(27.2 \%)$

Where caregiver normally gets traditional medicine $\mathbf{b}^{\mathbf{b} * * *}$

\begin{tabular}{|c|c|c|c|c|c|}
\hline $\mathbf{T M P} * * *$ & $18(36 \%)$ & 19 (35.9\%) & $13(26 \%)$ & $51(96.2 \%)$ & $101(49 \%)$ \\
\hline Church / Faith healer & $4(8 \%)$ & $8(15.1 \%)$ & 7 (14\%) & $4(7.6 \%)$ & $23(11.2 \%)$ \\
\hline Muthi shop ${ }^{\mathrm{d}}$ & $3(6 \%)$ & $3(5.7 \%)$ & $3(6 \%)$ & $0(0 \%)$ & $9(4.4 \%)$ \\
\hline Relative / garden / bush *** & $22(44 \%)$ & $25(47.2 \%)$ & $26(52 \%)$ & $3(5.7 \%)$ & $76(36.9 \%)$ \\
\hline \multicolumn{6}{|l|}{ Reasons for using a traditional healer b c } \\
\hline Supernatural problem / abantu illness & $21(30.9 \%)$ & $14(20.6 \%)$ & 17 (25\%) & $16(23.5 \%)$ & $68(100 \%)$ \\
\hline Inefficacy of Western medicine $* * *$ & $3(8.6 \%)$ & $3(8.6 \%)$ & $0(0 \%)$ & 29 (82.9\%) & $35(100 \%)$ \\
\hline Background / family influence * & $1(4.3 \%)$ & 9 (39.1\%) & $4(17.4 \%)$ & $9(39.1 \%)$ & $23(100 \%)$ \\
\hline
\end{tabular}

Why do you not take your child to a TMP?

\begin{tabular}{|c|c|c|c|c|c|}
\hline Doesn't believe & 7 (21.9\%) & $13(40.6 \%)$ & $12(37.5 \%)$ & $0(0 \%)$ & $32(100)$ \\
\hline Religion & $4(17.4 \%)$ & 10 (43.5\%) & $9(39.1 \%)$ & $0(0 \%)$ & $23(100)$ \\
\hline Background / family ${ }^{\mathrm{d}}$ & $4(33.3 \%)$ & $2(16.7 \%)$ & $6(50 \%)$ & $0(0 \%)$ & $12(100)$ \\
\hline \multicolumn{6}{|l|}{ Traditional medicine dangerous / not } \\
\hline as effective $^{\mathrm{d} *}$ & $9(64.3 \%)$ & $2(14.3 \%)$ & $3(21.4 \%)$ & $0(0 \%)$ & $14(100)$ \\
\hline \multicolumn{6}{|l|}{ Does faith healing work? ** } \\
\hline Yes & $20(40 \%)$ & $15(28.3 \%)$ & $10(20 \%)$ & $21(39.6 \%)$ & $66(32 \%)$ \\
\hline No & $10(20 \%)$ & $15(28.3 \%)$ & $9(18 \%)$ & $13(24.5 \%)$ & $47(22.8 \%)$ \\
\hline Depends on illness / belief / healer & $2(4 \%)$ & $7(13.2 \%)$ & $15(30 \%)$ & $3(5.6 \%)$ & $27(13.1 \%)$ \\
\hline Not sure & $18(36 \%)$ & $16(30.2 \%)$ & $16(32 \%)$ & $16(30.2 \%)$ & $66(32 \%)$ \\
\hline
\end{tabular}




\section{Use Dutch medicines for child?}

\begin{tabular}{|c|c|c|c|c|c|}
\hline Yes & 43 (86\%) & 43 (81.1\%) & 30 (60\%) & 44 (83\%) & $160(77.7 \%)$ \\
\hline No & 7 (14\%) & 10 (18.9\%) & 20 (40\%) & $9(16.9 \%)$ & 46 (22.3\%) \\
\hline \multicolumn{6}{|c|}{ Who decides what to do when child is not well? *** } \\
\hline Mother of child & 25 (50\%) & 27 (50.9\%) & 18 (36\%) & 17 (32.1\%) & 87 (42.2\%) \\
\hline Both parents & $17(34 \%)$ & $15(28.3 \%)$ & $30(60 \%)$ & $10(18.9 \%)$ & $72(34.9 \%)$ \\
\hline Grandmother & $4(8 \%)$ & $6(11.3 \%)$ & $1(2 \%)$ & 19 (35.9\%) & 30 (14.6\%) \\
\hline Other relative & $4(8 \%)$ & $5(9.4 \%)$ & $1(2 \%)$ & 7 (13.2\%) & 17 (8.3\%) \\
\hline \multicolumn{6}{|c|}{$\begin{array}{l}\text { a Includes } 7 \text { who had not yet given their child traditional medicine because they had not yet had inyoni or ibala } \\
\text { although they believed in its use. }\end{array}$} \\
\hline \multicolumn{6}{|c|}{ b Respondent may give more than one response, therefore column \% are not applicable. } \\
\hline \multicolumn{6}{|c|}{ c Only includes those who had used traditional medicine. } \\
\hline \multicolumn{6}{|c|}{${ }^{\mathrm{d}}$ Fishers Exact Test if expected cell $<5$} \\
\hline$\chi^{2} \mathrm{P}$ value ${ }^{*} p<0.0$ & & & & & \\
\hline
\end{tabular}


Table 3: Dutch medicines used by caregivers for their child under 6 by facility on day of interview

\begin{tabular}{|c|c|c|c|c|c|}
\hline Dutch medicine & $\begin{array}{c}\text { PHC (\%) } \\
(n=50)\end{array}$ & $\begin{array}{c}\text { Pub hosp (\%) } \\
(n=53)\end{array}$ & $\begin{array}{l}\text { Pvt clinic (\%) } \\
\qquad(n=50)\end{array}$ & $\begin{array}{c}\text { TMP (\%) } \\
(n=53)\end{array}$ & $\begin{array}{c}\text { Total (\%) } \\
(\mathrm{N}=206)\end{array}$ \\
\hline Balsem Kopiva $^{\text {a }}$ & 10.0 & 5.7 & 8.0 & 1.9 & 6.3 \\
\hline Behoedmiddel & 12.0 & 11.3 & 30.0 & 0.0 & 13.1 \\
\hline Borsdruppels & 22.0 & 9.4 & 18.0 & 7.5 & 14.1 \\
\hline Duiwelsdrek & 8.0 & 5.7 & 4.0 & 0.0 & 4.4 \\
\hline Duiwelsdrekdruppels & 6.0 & 1.9 & 8.0 & 0.0 & 3.9 \\
\hline Doepa & 28.0 & 18.9 & 20.0 & 34.0 & 25.2 \\
\hline Entressdruppels $^{\text {a }}$ & 34.0 & 24.5 & 36.0 & 24.5 & 29.6 \\
\hline Essens Groen Amara ${ }^{b}$ & 38.0 & 32.1 & 34.0 & 18.9 & 30.6 \\
\hline Haarlemensis $^{\text {a }}$ & 82.0 & 64.2 & 54.0 & 64.2 & 66.0 \\
\hline Jamaika Gemmer & 2.0 & 3.8 & 12.0 & 1.9 & 4.9 \\
\hline Krampdruppels $^{\text {a }}$ & 4.0 & 5.7 & 16.0 & 1.9 & 6.8 \\
\hline Paragoriese & 0.0 & 0.0 & 2.0 & 0.0 & 0.5 \\
\hline Rooilavental & 14.0 & 7.5 & 18.0 & 0.0 & 9.7 \\
\hline Staaldruppels & 6.0 & 1.9 & 4.0 & 0.0 & 2.9 \\
\hline
\end{tabular}




\begin{tabular}{|c|c|c|c|c|c|}
\hline Stuipdruppels ${ }^{\text {b }}$ & 56.0 & 32.1 & 34.0 & 35.8 & 39.3 \\
\hline Turlington & 4.0 & 0.0 & 2.0 & 0.0 & 1.5 \\
\hline Versterkdruppels & 2.0 & 1.9 & 2.0 & 0.0 & 1.5 \\
\hline Witdulsies & 6.0 & 5.7 & 6.0 & 0.0 & 4.4 \\
\hline Wonderkroonessens ${ }^{\text {a }}$ & 2.0 & 1.9 & 4.0 & 0.0 & 1.9 \\
\hline
\end{tabular}

${ }^{a}$ Nothing mentioned in instruction leaflet about children

${ }^{\mathrm{b}}$ Not for use in children 
Table 4: Selected variables associated with use of traditional medicine

\begin{tabular}{|c|c|c|c|}
\hline & \multicolumn{2}{|c|}{ Use of traditional medicine for child } & \multirow{3}{*}{$\begin{array}{l}\text { Total } \\
(\mathrm{N}=206)\end{array}$} \\
\hline & Has given / would give & Has never / would never & \\
\hline & $(n=150)$ & $(n=56)$ & \\
\hline \multicolumn{4}{|l|}{ Religion ** } \\
\hline Catholic & $15(68.2 \%)$ & $7(31.8 \%)$ & $22(100 \%)$ \\
\hline ZCC & 40 (88.9\%) & $5(11.1 \%)$ & $45(100 \%)$ \\
\hline AIC & $43(75.4 \%)$ & $14(24.6 \%)$ & $57(100 \%)$ \\
\hline Protestant & $36(58.1 \%)$ & $26(41.9 \%)$ & $62(100 \%)$ \\
\hline None & $16(80 \%)$ & $4(20 \%)$ & $20(100 \%)$ \\
\hline \multicolumn{4}{|c|}{ Main decision-maker about child's health care * } \\
\hline Mother of child & $56(64.4 \%)$ & $31(35.6 \%)$ & $87(100 \%)$ \\
\hline Both parents & $52(72.2 \%)$ & $20(27.8 \%)$ & $72(100 \%)$ \\
\hline Granny & $28(93.3 \%)$ & $2(6.7 \%)$ & $30(100 \%)$ \\
\hline Other relative & $14(82.4 \%)$ & $3(17.7 \%)$ & $17(100 \%)$ \\
\hline \multicolumn{4}{|l|}{ SES score $* *$} \\
\hline Very low & $39(82.9 \%)$ & $8(17 \%)$ & $47(100 \%)$ \\
\hline Low & $50(75.7 \%)$ & $16(24.2 \%)$ & $66(100 \%)$ \\
\hline Medium & $40(78.4 \%)$ & $11(21.6 \%)$ & $51(100 \%)$ \\
\hline
\end{tabular}


High

21 (50\%)

21 (50\%)

42 (100\%)

Caregiver's highest education level reached **

\begin{tabular}{lrrr}
\hline $\begin{array}{l}\text { None / complete primary } \\
\text { Some secondary }\end{array}$ & $2(6.3 \%)$ & $32(100 \%)$ \\
Complete secondary & $54(72.9 \%)$ & $20(27 \%)$ & $74(100 \%)$ \\
Higher & $42(72.4 \%)$ & $16(27.6 \%)$ & $58(100 \%)$ \\
\hline$\chi^{2}$ P value ${ }^{*} p<0.05 ; * * p<0.01$ & $18(42.9 \%)$ & $42(100 \%)$ \\
\hline
\end{tabular}




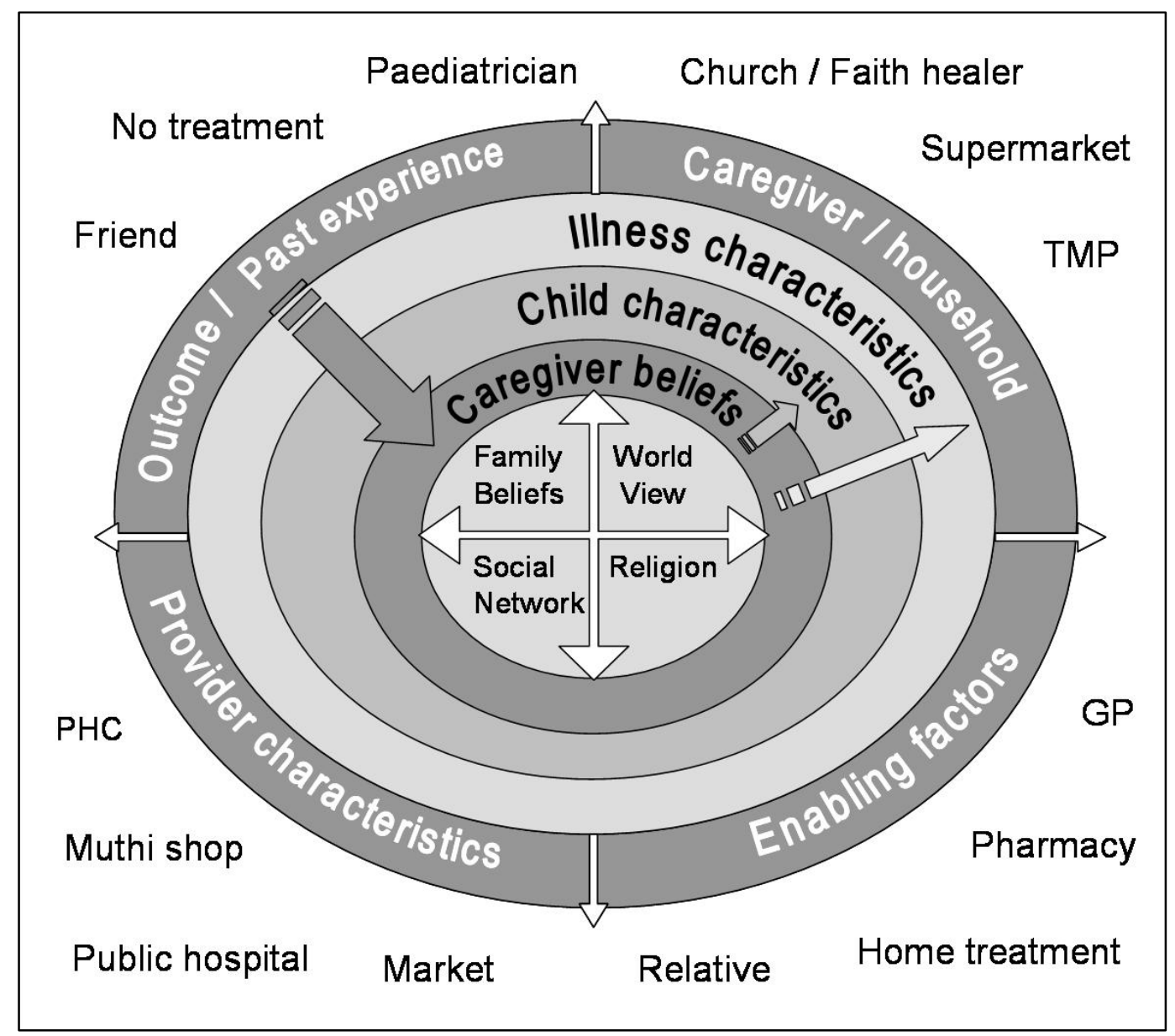

Figure 1: Spheres of influence on perception and treatment of abantu childhood illnesses in urban South Africa 


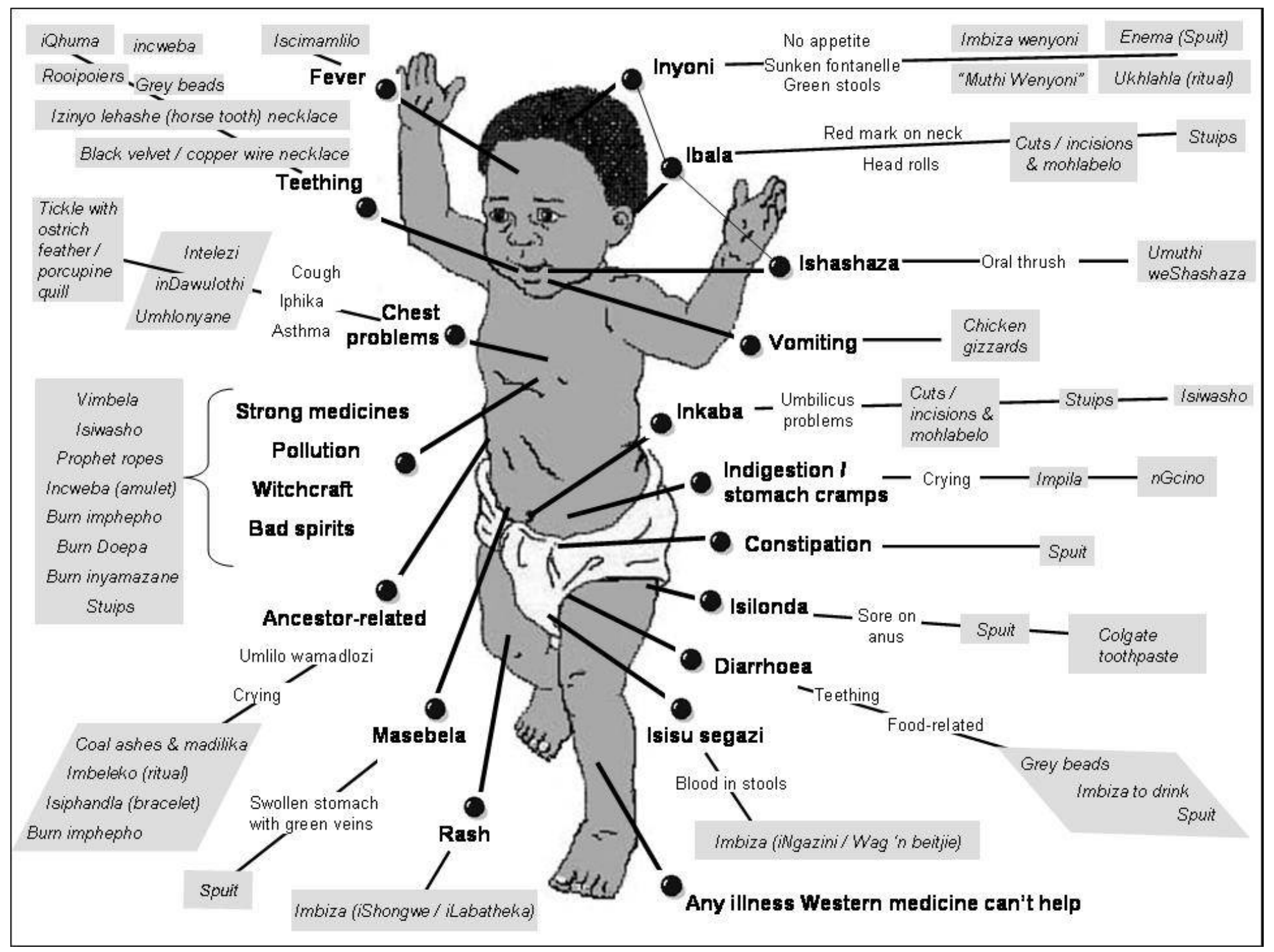

Figure 2: Management of abantu and other childhood health problems with non-allopathic medicines 